\title{
A study of incidence of palatal side abfractions in maxillary posterior teeth
}

\author{
Joo-Hun Song, Yuri Heo, Gyeong-Je Lee* \\ Department of Prosthodontics, College of Dentistry, Chosun University, Gwangju, Republic of Korea
}

\begin{abstract}
Purpose: Most of studies dealing with abfractions are limited to the buccal surfaces of the teeth. In this study, we analyzed the cause for abfraction by investigating the incidence of palatal side abfractions in maxillary posterior teeth. Materials and Methods: We investigated a total of 3193 maxillary posterior teeth by an intraoral examination, model observation, and observation of virtual model fabricated using model scanning. We recorded the results and classified them depending on the type of teeth, age, gender, and side of arches. We also performed Chi-square test to evaluate the statistical significance among the groups $(\alpha=0.05)$. Results: The incidence of palatal side abfraction of the maxillary molars (10.8\%) was higher than the premolars $(6.8 \%)$, and among them, the incidence of the 1st molars (39.1\%) were the highest. The incidence of palatal side abfraction increased with age and was statistically significant $(P<0.05)$. There was no statistical significance in the difference by gender $(P>0.05)$; in the case of arches, left arch showed higher incidence and it was statistically significant $(P<0.05)$. Conclusion: Palatal side abfraction in maxillary posterior teeth was frequently observed in the maxillary 1st molars, and the incidence increased with age. This result suggests that the main reason for abfraction is due to occlusal force. (J Dent Rehabil Appl Sci 2019;35(4):206-13)
\end{abstract}

Key words: tooth fractures; tooth abrasion; tooth attrition; occlusal force

\begin{abstract}
서론
비우식성 치경부 병소(NCCLs, non-carious cervical lesion)는 치아의 정상적 기능 또는 이상기능동안 생 긴 치질의 마모 또는 파절을 뜻하는 것으로, 굴곡파절 (abfraction), 마모(abrasion), 침식(erosion)등이 있다. ${ }^{1}$

이 병소에 대해 초기에 연구가 이루어졌을 때, 굴곡파 절과 침식, 마모와 같은 비우식성 치경부 병소를 의미하 는 용어들이 정확하게 정의되지 않았고, 이는 이에 대한 병소의 원인 분석과 치료에 어려움을 주었다. ${ }^{2} 1900$ 년대 초반에는 이 병소에 대한 원인을 치약과 칫솔에 의한 마 모에서 찾았다. ${ }^{3}$
\end{abstract}

*Correspondence to: Gyeong-Je Lee

Professor, Department of Prosthodontics, College of Dentistry, Chosun University, 309, Pilmun-daero, Dong-gu, Gwangju, 61452, Republic of Korea

Tel: +82-62-220-3827, Fax: +82-62-232-7776, E-mail: Ikj1998@chosun.ac.kr Received: September 2, 2019/Last Revision: September 16, 2019/Accepted: September 25, 2019
Lee와 Eakle ${ }^{4}$ 은 비우식성 치경부 병소의 원인이 교합 력이 가해졌을 때 발생하는 장력이라고 주장하였고, 이 후 교합력이 가장 유력한 원인으로 주목받았다. 그리고 교합력에 의해 생긴 파절은 $\mathrm{Grippo}^{5}$ 에 의해 굴곡파절로 명명되었다. Grippo ${ }^{5}$ 는 굴곡파절은 생역학적인 자극, 즉 교합력에 의한 병적인 치질의 상실이라고 정의 내렸으며, 치아에 하중이 가해졌을 때 치아에 나타나는 휨으로 인 해 굴곡파절이 나타난다고 하였다.

굴곡파절과 교합력 사이의 관계를 밝히기 위해 많은 연구가 이루어졌다. 다수 연구들에서 교합력이 가해졌 을 때 치경부 부위에 인장력이 발생하고, 이는 굴곡파절 에 영향을 준다는 결과들이 보고되었다. ${ }^{6-15}$ 그러나 교합

Copyright(C) 2019 The Korean Academy of Stomatognathic Function and Occlusion. (c) It is identical to Creative Commons Non-Commercial License. 
력과 굴곡파절의 연관성이 약하다는 연구 결과도 존재한 다. ${ }^{16,17}$ Nascimento 등 ${ }^{18}$ 은 굴곡파절을 가진 모든 환자에 서 교합면 마모를 보이는 건 아니며, 교합면 마모를 가진 모든 환자들에게서 비우식성 치경부 병소가 존재하지 않 는다는 점에서, 비우식성 치경부 병소와 교합력과의 연관 성은 약하다고 주장하였다

비우식성 치경부 병소의 발생 빈도에 대해서도 여러 연 구가 진행되었다. Shulman과 Robinson ${ }^{19}$ 은 $2 \%$ 로 보고 하였고, Bregstrom과 Eliasson ${ }^{20}$ 은 $90 \%$ 에서 관찰되었다 고 하였다. 위의 차이점은 Shulman과 Robinson ${ }^{19}$ 은 어린 남성을 대상으로 연구하였고, Bregstrom과 Eliasson ${ }^{20}$ 은 31 - 60세의 연령을 대상으로 연구하였기 때문으로 보인 다. Levitch 등 ${ }^{21}$ 은 여러 논문을 살펴봤을 때, 5 - 85\% 범 위의 유병률이 보고되었고 나이와 강한 연관성이 있다고 하였다. Smith 등 ${ }^{22}$ 도 $62.2 \%$ 에서 비우식성 치경부 병소 가 관찰되었고, 연령이 증가할수록 더 높은 빈도로 관찰 된다고 하였다.

비우식성 치경부 병소의 치료는 주로 수복해주는 방법 으로 이루어지지만, ${ }^{23}$ 수복물의 잦은 탈락은 치료 방법에 대해 많은 혼란을 야기하고있다. ${ }^{24}$ 병소의 원인과 치료 방법 모두 확실하게 밝혀지지 않은 상황이며, 임상가들은 여전히 명확한 지침 없이 경험에 따라 치료를 하고있다.

굴곡파절은 주로 협측에 나타난다. ${ }^{11,25}$ 굴곡파절에 대 한 유병률과 원인에 관한 연구들은 다수 이루어져왔지 만, ${ }^{6-15,25}$ 구개측에 한정된 굴곡파절에 대해 연구는 거의 이루어지지 않았다. 비우식성 치경부 병소의 원인 중 하 나로 생각되는 칫솔질 같은 기계적 자극, ${ }^{3,21,26}$ 그리고 타 액의 완충 능력이 치질에 미치는 영향, ${ }^{2}$ 이같은 원인을 제 외하고 굴곡파절의 원인을 살펴볼 수 있다는 점에서, 상 악 구치에서 구개측 굴곡파절에 한정된 연구는 의미가 있다. 본 연구에서는 상악 구치에서 구개측의 굴곡파절 의 빈도를 조사하여, 원인 및 치료방법의 제시에 도움이 되고자 한다.

\section{연구 재료 및 방법}

조선대학교 치과병원에 2015년부터 2019년까지 내원 한 환자들을 대상으로 조사하였다. 18세부터 88세(평균 50.9세)의 524명(남성 271명, 여성 253명)을 대상으로 조 사를 진행하였다(Table 1). 구내 관찰은 20 명, 모형 관찰 은 46명, 그리고 모형 스캔을 통해 제작된 가상 모형은 458명, 총 524명을 관찰하였다. 조선대학교 치과병원 임 상시험 심사위원회의를 거친 후(CUDHIRB 1706 006) 연구를 진행하였다.

\section{구내 검사, 모형 관찰, CAD (Computer Aided Design) 자료 조사}

총 3193개의 상악 구치(상악 소구치 1715개, 상악 대 구치 1478 개)를 대상으로 조사를 진행하였다. 굴곡파절 을 결정하는 명확한 깊이에 대한 지침은 존재하지 않지 만, 명확한 구개측 굴곡파절의 구분을 위해 Estafan 등 ${ }^{17}$ 의 연구를 참고하여 상악의 소구치, 대구치에서 깊이 0.5 $\mathrm{mm}$ 이상의 구개측 굴곡파절만 기록하였다(Fig. 1). 구내 검사와 모형 관찰에서는 탐침을 이용하여 깊이를 측정하 였으며, CAD자료에서는 디지털 모형상에서의 깊이 측 정 도구를 이용하여 측정하였다. 상악 구치에서 구개측 굴곡파절이 존재하는 치아와 존재하지 않는 치아를 각각 기록하였으며, 환자의 나이와 성별도 함께 기록하였다. 침식과 마모는 구개측 굴곡파절로 분류하지 않았다. 발

Table 1. Participants in this study

\begin{tabular}{lcc}
\hline & Number & Mean age (year) \\
\hline Male & 271 & 52.1 \\
Female & 253 & 49.5 \\
Total & 524 & 50.9 \\
\hline
\end{tabular}
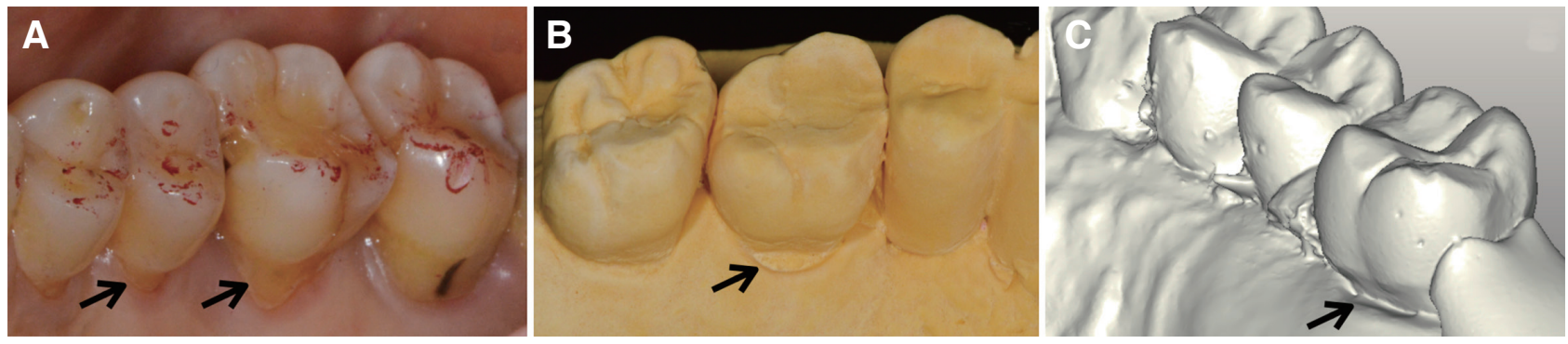

Fig. 1. Palatal side abfractions (arrow). (A) Oral examination, (B) Cast, (C) CAD (Computer Aided Design). 
현율에 대한 평가를 위해 정상 치아의 개수도 측정하였 으며, 전장관 수복으로 구개측 치경부 관찰이 불가능한 치아와 상실치는 분류에서 제외하였다.

\section{조사 대상의 분류}

상악 구치에서 각 치아별로 구개측 굴곡파절이 있는 치아의 수를 기록하였다. 상악 제 1 소구치, 제 2 소구치, 제 1 대구치, 제 2 대구치 각각의 치아에서 구개측 굴곡파절의 존재 여부를 기록하였다(Table 2).

상악 구치에서 연령대별 차이, 성별에 따른 차이, 좌측 과 우측에 따른 차이를 알아보고자, 각 분류별 구개측 굴 곡파절의 존재 여부를 기록하였다.

\section{통계학적 분석}

SPSS 통계 분석 프로그램(IBM SPSS Statistics 22.0, SPSS INC., Chicago, USA)을 이용하였다. 그룹간의 통 계적 유의성을 평가하기 위해 Chi-square test를 시행하 였다 $(\alpha=0.05)$.

Table 2. Number of teeth which have palatal side abfraction in maxillary posterior teeth by tooth type

\begin{tabular}{llr}
\hline Without abfraction & 2917 & \\
\hline & $1^{\text {st }}$ premolar & 53 \\
& $2^{\text {nd }}$ premolar & 63 \\
With abfraction & $1^{\text {st }}$ molar & 108 \\
& $2^{\text {nd }}$ molar & 52 \\
& Total & 276 \\
\hline
\end{tabular}

Out of 3193 teeth, 276 teeth exhibited palatal side abfractions. Depending on the tooth type, $1^{\text {st }}$ premolar accounted for 53 teeth, $2^{\text {nd }}$ premolar 63 teeth, $1^{\text {st }}$ molar 108 teeth, and $2^{\text {nd }}$ molar accounted for 52 teeth.

\section{결과}

총 3193개의 상악 구치를 대상으로 조사하였고, 소구 치와 대구치에서 구개측 굴곡파절을 관찰하였다. 전체 상악 구치 중 구개측 굴곡파절은 276개(8.6\%)의 치아에 서 나타났고(Table 3), 치아별 비율은 소구치에서 $6.8 \%$, 대구치에서 $10.8 \%$ 의 치아에서 나타났다. 상악 구치에서 구개측 굴곡파절이 나타난 치아 중 각 치아별 분포를 살 펴보면 제 1 소구치에서 $19.2 \%$, 제 2 소구치에서 $22.8 \%$, 제 1 대구치에서 $39.1 \%$, 제 2 대구치에서 $18.8 \%$ 의 비율로 나 타났다(Fig. 2).

상악 구치에서 연령별로 비교하여 살펴보면, 각 연령별 조사한 치아 대비 구개측 굴곡파절의 비율이 29세 이하 에서 $1.3 \%, 30$ - 39세에서 $3.9 \%, 40$ - 49세에서 7.4\%, 50 - 59세에서 $10.5 \%, 60$ - 69세에서 $15.1 \%, 70$ 세 이상에서

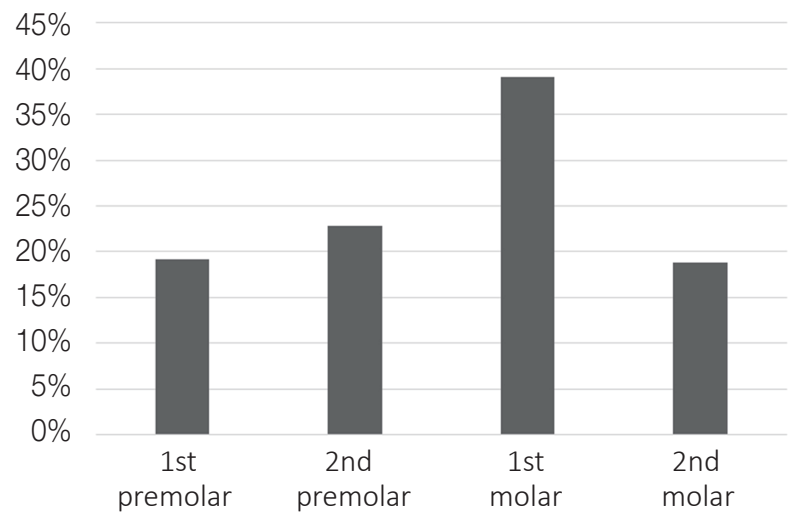

Fig. 2. Distribution of palatal side abfractions in maxillary molar and premolar. Out of 3193 teeth, 276 teeth exhibited palatal side abfractions. When manifestation of palatal side abfraction was classified depending on the type of teeth, 1st premolar accounted for 19.2\% (53 teeth), 2nd premolar $22.8 \%$ (63 teeth), 1st molar $39.1 \%$ (108 teeth), and 2nd molar accounted for 18.8\% (52 teeth).

Table 3. Incidence ratio of palatal side abfractions in maxillary posterior teeth

\begin{tabular}{lccc}
\hline & Premolar & Molar & Total \\
\hline Without abfraction & $1599(93.2 \%)$ & $1318(89.2 \%)$ & $2917(91.4 \%)$ \\
With abfraction & $116(6.8 \%)$ & $160(10.8 \%)$ & $276(8.6 \%)$ \\
Total & 1715 & 1478 & 3193 \\
\hline
\end{tabular}

The ratio of maxillary posterior teeth manifested palatal side abfractions in premolars were 116 (6.8\%), and 160 (10.8\%) for molars. 
$9.9 \%$ 의 비율을 보였다(Fig. 3). 70 대 이상을 제외하고 연 령이 증가함에 따라 구개측 굴곡파절이 증가하는 양상 을 보였고, 통계학적으로 유의한 차이가 $(P<0.05)$ 나타 났다(Table 4).

성별의 차이를 살펴보면, 상악 구치의 구개측 굴곡파절 은 남성에서 $9.5 \%$ 의 빈도로 나타났고, 여성에서 $7.8 \%$ 의 빈도로 나타났다. 이는 통계학적으로 유의한 차이가 $(P>$ 0.05) 나타나지 않았다(Table 5).

좌,우측에 따른 차이를 살펴보면, 상악 구치의 구개측 굴곡파절이 우측에서는 $7.5 \%$ 의 비율로 나타났고, 좌측 에서는 $9.8 \%$ 의 비율로 나타났다. 이는 통계학적으로 유 의한 차이를 $(P<0.05)$ 보였다 (Table 6$)$.

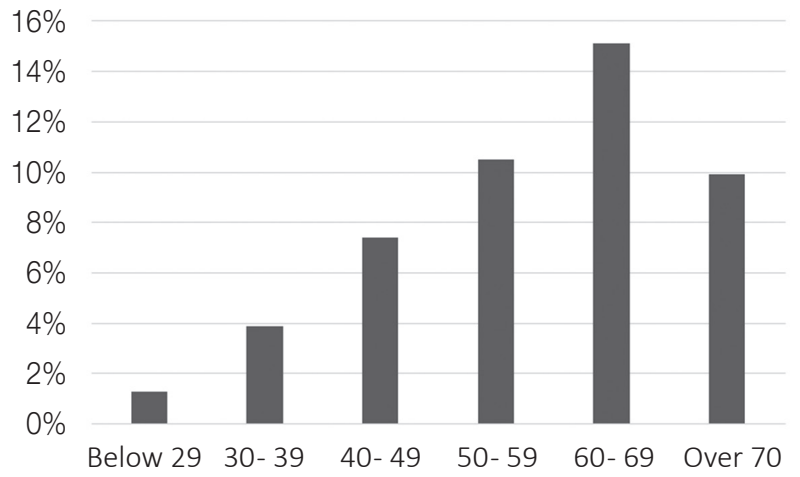

Fig. 3. Distribution of palatal side abfractions according to the age. The ratio of palatal side abfraction in maxillary posterior teeth surveyed for each age was $1.3 \%$ under 29 years of age, $3.9 \%$ for $30-39,7.4 \%$ for 40 $49,10.5 \%$ for $50-59,15.1 \%$ for $60-69$, and $9.9 \%$ for 70 years old and above.

Table 4. Incidence ratio of palatal side abfractions in maxillary posterior teeth by age

\begin{tabular}{lcccccccc}
\hline & Below 29 & $30-39$ & $40-49$ & $50-59$ & $60-69$ & Over $^{70}$ & Total & $\mathrm{X}^{2}$ \\
\hline Without abfraction & $443(98.7 \%)$ & $317(96.1 \%)$ & $648(92.6 \%)$ & $785(89.5 \%)$ & $496(84.9 \%)$ & $228(90.1 \%)$ & 2917 & \\
With abfraction & $6(1.3 \%)$ & $13(3.9 \%)$ & $52(7.4 \%)$ & $92(10.5 \%)$ & $88(15.1 \%)$ & $25(9.9 \%)$ & 276 & 75.723 \\
Total & 449 & 330 & 700 & 877 & 584 & 253 & 3193 & $(\mathrm{df}=5)$ \\
\hline
\end{tabular}

Chi-square test, $P$-value $=0.000, \alpha=0.05$.

In terms of age, ratio of palatal side abfraction in maxillary posterior teeth surveyed for each age was $6(1.3 \%)$ under 29 years of age, $13(3.9 \%)$ for 30 - 39, $52(7.4 \%)$ for 40 - 49, $92(10.5 \%)$ for 50-59, $88(15.1 \%)$ for 60-69, and $25(9.9 \%)$ for 70 years old and above.

Table 5. Incidence ration of palatal side abfractions in maxillary posterior teeth by gender

\begin{tabular}{lccrl}
\hline & Male & Female & Total & $\mathrm{X}^{2}$ \\
\hline Without abfraction & $1504(90.5 \%)$ & $1413(92.2 \%)$ & 2917 & $2.864(\mathrm{df}=1)$ \\
With abfraction & $157(9.5 \%)$ & $119(7.8 \%)$ & 276 & 3193 \\
Total & 1661 & 1532 & & \\
\hline
\end{tabular}

Chi-square test, $P$-value $=0.091, \alpha=0.05$.

In terms of gender, palatal side abfractions in maxillary posterior teeth occurred in $157(9.5 \%)$ of males and in $119(7.8 \%)$ of females.

Table 6. Incidence ratio of palatal side abfractions in maxillary posterior teeth according to the arch

\begin{tabular}{lccrc}
\hline & Right & Left & Total & $\mathrm{X}^{2}$ \\
\hline Without abfraction & $1486(92.5 \%)$ & $1431(90.2 \%)$ & 2917 & $5.088(\mathrm{df}=1)$ \\
With abfraction & $121(7.5 \%)$ & $155(9.8 \%)$ & 276 & 3193 \\
Total & 1607 & 1586 & & \\
\hline
\end{tabular}

Chi-square test, $P$-value $=0.024, \alpha=0.05$.

In terms of the sides of the dental arch, the incidence of palatal side abfractions in maxillary posterior teeth was $121(7.5 \%)$ for the right side and $155(9.8 \%)$ for left side of the arch. 


\section{고찰}

굴곡파절의 정의를 내린 Grippo 등 ${ }^{27}$ 은 원인을 한가지 로 정하여 이야기하는 것은 바람직하지 않다고 하였다. 현재 임상적으로 굴곡파절이 있을 때 가장 일반적인 치 료는 결손 부위를 수복해주는 것이다. ${ }^{23}$ 그러나 수복 후 잦은 수복물의 탈락이 발생한다. ${ }^{24}$ 이는 이 병소에 대한 원인 파악이 여전히 부족하며, 이에따라 치료방법도 논 쟁거리가 있다는 것을 의미한다. 이에 본 연구에서는 다 른 원인 요소를 배제시키기 위해 상악 구치에서의 구개 측 굴곡파절에 한정하여 연구를 시행하였다.

상악 구치에서 구개측 굴곡파절은 상악 대구치 $(10.8 \%)$ 에서 상악 소구치(6.8\%)보다 많이 나타났다. 상 악 구치에서 구개측 굴곡파절이 나타난 치아 중 각 치 아 별 분포는 제 1 대구치(39.13\%)에서 가장 많이 나타났 고, 두번째로는 제 2 소구치(22.82\%)에서 많이 나타났으 며, 이후로는 제 1 소구치(19.2\%), 제 2 대구치 $(18.8 \%)$ 순서 로 나타났다. 비우식성 치경부 병소의 발생 빈도 대구치 보다는 소구치에서 더 흔하게 나타난다는 연구도 있고, ${ }^{4}$ 그와는 반대로 대구치에서 더 흔하게 나타난다는 연구도 있다. ${ }^{26}$ 본 연구에서는 상악 구치에서 구개측 굴곡파절이 소구치보다는 대구치에서 더 흔하게 나타났다. 연구마다 다른 결과가 나타난 부분은, 위의 연구들 당시 아직 비우 식성 치경부 병소의 정의 및 분류가 명확하지 않고, 이에 따라 연구 결과의 차이가 나타난 것으로 사료된다. 본 연 구에서는 명확한 구개측 굴곡파절이 존재할 때만 해당 치아를 분류하였다. 상악 구치에서 소구치 보다 대구치 에서 병소가 더 많이 관찰이 되고 특히 교합력이 가장 많 이 가해지는 치아인 제 1 대구치에서 가장 많은 비율로 나 타난 것을 고려해보면, ${ }^{28}$ 굴곡파절의 가장 큰 요인은 교 합력이라고 판단될 수 있다.

본 연구에서는 한 그룹과 다른 그룹의 분포를 비교하 여 그룹간의 통계적 유의성을 평가하기 위해 Chi-square test를 시행하였다. 연령에 따른 상악 구치의 구개측 굴곡 파절의 빈도를 살펴보면, 70 대 이상을 제외하고 연령이 증가함에 따라 더 많은 빈도로 나타났다. 특히 29세 이하 에서는 매우 적은 빈도로 나타났고, 60 - 69세에서 가장 많은 빈도로 나타났으며, 이러한 차이는 통계학적으로 유의성 있게 나타났다. 이는 연령이 증가함에 따라 비우 식성 치경부 병소의 발생 빈도도 증가한다는 다른 연구 결과와 일치한다. ${ }^{21,22,29} 70$ 대 이상에서 감소한 결과가 나 타났다. 이는 70 대 이상에서는 대구치부의 상실 또는 보
철물의 수가 많았고 이 때문에 다소 감소한 수치가 나타 난 것으로 사료되며 이에 대한 추가 연구가 필요해 보인 다. 연령이 증가할수록 견치유도보다 군기능유도가 증 가하고 ${ }^{30}$ 견치유도보다 군기능유도에서 더 많은 비우식 성 치경부 병소가 관찰되었다는 연구가 있다. ${ }^{14,15}$ 군기능 유도일때 구치부에서의 치아 접촉은 치아의 휨을 야기할 수 있고, ${ }^{15}$ 치아의 휨은 법랑소주를 파괴시킬 수 있으며 여기에 교합력이 가해졌을 때 치경부 치질 손상이 발생 할 수 있다. ${ }^{31,32}$ 본 연구에서 연령이 증가함에 따라 상악 구치의 구개측 굴곡파절의 빈도가 증가한 결과를 고려해 봤을 때, 교합력이 굴곡파절의 중요한 원인이라고 판단 될 수 있다.

상악 구치에서 성별에 따른 구개측 굴곡파절은 남성 $(9.5 \%)$ 에서 여성 $(7.8 \%)$ 보다 더 많이 나타났지만 이와 같 은 차이는 통계학적으로 유의성 있는 차이는 아니었다. 굴곡파절의 원인 중 하나로 교합력이 고려되지만, 오직 교합력만을 굴곡파절의 이유로 판단하는 것은 바람직하 지 않다. ${ }^{27}$ 남성에서 보다 많은 비율로 나타난 부분은 교 합력과 연관이 있을 것으로 판단되지만, 유의한 차이가 아니었다는 점에서 그 이외의 원인들에 대해서도 고려가 필요할 것으로 사료된다.

좌우에 따른 상악 구치의 구개측 굴곡파절의 비교는 통계학적으로 유의성 있는 차이가 나타났다. 좌측의 소 구치와 대구치부에서 $9.8 \%$ 로, 우측 소구치와 대구치부 의 $7.5 \%$ 보다 더 많은 비율로 관찰되었다. 편측 저작 등의 요인들이 이와 같은 결과와 연관이 있을 것으로 판단된 다. 보다 정확한 원인을 알기 위해선 실제 환자의 구강내 상태와 식습관을 분석해봐야 알 수 있을 것으로 보이며, 이를 위해 추가적인 연구가 필요할 것으로 사료된다.

1 년동안 치아는 저작과 연하의 과정 동안 대략 100 만 번 정도의 접촉이 일어난다. ${ }^{33}$ 이와 같이 많은 수의 치아 접촉 및 교합력이 가해지는 동안 치아는 변형이 일어날 수 있고, 이와 같은 변형은 치질의 파절로 이어질 수 있 다. 다수의 연구들에서 교합력이 굴곡파절의 주된 원인 일 수 있음을 보였다. ${ }^{6-12}$ 그렇지 않다는 연구들도 있지만, Estafan 등 ${ }^{17}$ 은 학생들을 대상으로 연구하였으며 어릴수 록 비우식성 치경부 병소가 적게 발생한다는 점을 생각 해볼 때, 교합면 마모가 관련이 없다는 주장은 근거가 빈 약해 보인다.

본 연구에서는 상악 구치에서 구개측 굴곡파절을 대상 으로 빈도를 조사하였고 결과를 분석하였다. 구개측 굴 곡파절은 상악 소구치보다는 상악 대구치부에서, 특히 
상악 제 1 대구치에서 가장 많은 빈도로 관찰되었다. 그리 고 연령이 증가할수록 상악 구치의 구개측 굴곡파절의 빈도가 증가하여 나타났다. 연령 증가에 따라 굴곡파절 이 증가한다는 사실은 논란의 여지는 없어 보인다. 그리 고 소구치보다 대구치에서 가장 많은 구개측 굴곡파절이 나타난 본 연구 결과는, 교합력이 굴곡파절의 주된 원인 으로 생각하는 근거가 될 수 있을 것으로 사료된다.

\section{결론}

상악의 소구치와 대구치에 대한 구개측 굴곡파절의 경 향을 조사한 결과, 다음과 같은 결과를 얻었다.

1. 대구치에서 보다 많은 구개측 굴곡파절이 관찰되었 고, 제 1 대구치에서 높은 빈도로 굴곡파절이 나타났 다.

2. 연령이 증가함에 따라 구개측 굴곡파절의 빈도도 증 가하였다.

3. 굴곡파절의 가장 주된 원인으로 교합력을 고려해야 한다.

\section{Acknowledgements}

이 논문은 2019년도 조선대학교 학술연구비의 지원을 받아 연구되었음.

\section{ORCID}

Joo-Hun Song https://orcid.org/0000-0003-4229-6148

Yuri Heo https://orcid.org/0000-0002-1806-3822

Gyeong-Je Lee https://orcid.org/0000-0002-3545-2280

\section{References}

1. Mjör IA. Pulp-dentin biology in restorative dentistry. Part 5: Clinical management and tissue changes associated with wear and trauma. Quintessence Int 2001;32:771-88.

2. Wood I, Jawad Z, Paisley C, Brunton P. Non-carious cervical tooth surface loss: a literature review. J Dent 2008;36:759-66.

3. Miller WD. Experiments and observations on the wasting of tooth tissue variously designated as erosion, abrasion, chemical abrasion, denudation, etc.
Dent Cosm 1907;49:1-23.

4. Lee WC, Eakle WS. Possible role of tensile stress in the etiology of cervical erosive lesions of teeth. J Prosthet Dent 1984;52:374-80.

5. Grippo JO. Abfractions: a new classification of hard tissue lesions of teeth. J Esthet Dent 1991;3:14-9.

6. Goel VK, Khera SC, Ralston JL, Chang KH. Stresses at the dentinoenamel junction of human teeth-a finite element investigation. J Prosthet Dent 1991;66:451-9.

7. Chen KK, Miyake K, Terashita M. Cervical strains induced by occlusal loading. J Dent Res 1999;78:474.

8. Nohl FS, McCabe JF, Walls AWG. The effect of load angle on strains induced in maxillary premolars in vitro. J Dent Res 1999;78:1059.

9. Dejak B, Mlotkowski A, Romanowicz M. Finite element analysis of mechanism of cervical lesion formation in simulated molars during mastication and parafunction. J Prosthet Dent 2005;94:520-9.

10. Lee HE, Lin CL, Wang $\mathrm{CH}$, Cheng $\mathrm{CH}$, Chang $\mathrm{CH}$. Stresses at the cervical lesion of maxillary premolar-a finite element investigation. J Dent 2002;30:283-90

11. Rees JS. The biomechanics of abfraction. Proc Inst Mech Eng H 2006;220:69-80.

12. Pintado MR, Delong R, Ko CC, Sakaguchi RL, Douglas WH. Correlation of noncarious cervical lesion size and occlusal wear in a single adult over a 14-year time span. J Prosthet Dent 2000;84:436-43.

13. Sawlani K, Lawson NC, Burgess JO, Lemons JE, Kinderknecht KE, Givan DA, Ramp L. Factors influencing the progression of noncarious cervical lesions: a 5-year prospective clinical evaluation. J Prosthet Dent 2016;115:571-7.

14. Brandini DA, Trevisan CL, Panzarini SR, Pedrini D. Clinical evaluation of the association between noncarious cervical lesions and occlusal forces. J Prosthet Dent 2012;108:298-303.

15. Antonelli JR, Hottel TL, Brandt R, Scarbecz M, Patel T. The role of occlusal loading in the pathogenesis of non-carious cervical lesions. Am J Dent 2013;26:86-92.

16. Wood ID, Kassir AS, Brunton PA. Effect of lateral excursive movements on the progression of abfrac- 
tion lesions. Oper Dent 2009;34:273-9.

17. Estafan A, Furnari PC, Goldstein G, Hittelman EL. In vivo correlation of noncarious cervical lesions and occlusal wear. J Prosthet Dent 2005;93:221-6.

18. Nascimento MM, Dilbone DA, Pereira PN, Duarte WR, Geraldeli S, Delgado AJ. Abfraction lesions: etiology, diagnosis, and treatment options. Clin Cosmet Investig Dent 2016;8:79-87.

19. Shulman EH, Robinson HB. Salivary citrate content and erosion of the teeth. J Dent Res 1948;27:541-4.

20. Bergström J, Eliasson S. Cervical abrasion in relation to toothbrushing and periodontal health. Scand J Dent Res 1988;96:405-11.

21. Levitch LC, Bader JD, Shugars DA, Heymann HO. Non-carious cervical lesions. J Dent 1994;22:195207.

22. Smith WA, Marchan S, Rafeek RN. The prevalence and severity of non-carious cervical lesions in a group of patients attending a university hospital in Trinidad. J Oral Rehabil 2008;35:128-34.

23. Nascimento MM, Gordan VV, Qvist V, Bader JD, Rindal DB, Williams OD, Gewartowski D, Fellows JL, Litaker MS, Gilbert GH; Dental Practice-Based Research Network Collaborative Group. Restoration of noncarious tooth defects by dentists in The Dental Practice-Based Research Network. J Am Dent Assoc 2011;142:1368-75.

24. Ichim IP, Schmidlin PR, Li Q, Kieser JA, Swain MV. Restoration of non-carious cervical lesions Part II. Restorative material selection to minimise fracture. Dent Mater 2007;23:1562-9.

25. Rees JS, Hammadeh M, Jagger DC. Abfraction lesion formation in maxillary incisors, canines and premolars: a finite element study. Eur J Oral Sci 2003;111:149-54.

26. Radentz WH, Barnes GP, Cutright DE. A survey of factors possibly associated with cervical abrasion of tooth surfaces. J Periodontol 1976;47:148-54.

27. Grippo JO, Simring M, Coleman TA. Abfraction, abrasion, biocorrosion, and the enigma of noncarious cervical lesions: a 20 -year perspective. J Esthet Restor Dent 2012;24:10-23.

28. Ferrario VF, Sforza C, Serrao G, Dellavia C, Tartaglia GM. Single tooth bite forces in healthy young adults. J Oral Rehabil 2004;31:18-22.

29. Harvey WL, Hatch RA, Osborne JW. Computerized occlusal analysis: an evaluation of the sensors. J Prosthet Dent 1991;65:89-92.

30. Yaffe A, Ehrlich J. The functional range of tooth contact in lateral gliding movements. J Prosthet Dent 1987;57:730-3.

31. Staninec M, Nalla RK, Hilton JF, Ritchie RO, Watanabe LG, Nonomura G, Marshall GW, Marshall SJ. Dentin erosion simulation by cantilever beam fatigue and $\mathrm{pH}$ change. J Dent Res 2005;84:371-5.

32. Whitehead SA, Wilson NH, Watts DC. Development of noncarious cervical notch lesions in vitro. J Esthet Dent 1999;11:332-7.

33. Sessle BJ. Mastication, swallowing, and related activities. Oral Biol St Louis CV Mosby Co. 1981.p.51-89. 


\section{상악 구치에서의 구개측 굴곡파절 발현 비율 연구}

\section{송주헌, 허유리, 이경제*}

조선대학교 치과대학 치과보철학교실

목적: 굴곡파절의 대부분 연구들이 협측에 한정되어있다. 본 연구에서는 상악 구치부에서 구개측 굴곡파절의 빈도 조사 를 통해 굴곡파절의 원인을 분석해보고자 한다.

연구 재료 및 방법: 총 3193개의 상악 구치를 대상으로 조사를 진행하였다. 구내 관찰과 모형 관찰, 그리고 모형 스캔을 통해 제작된 가상 모형을 관찰하는 방법으로 조사를 진행하였다. 그 결과를 치아, 연령, 성별, 악궁에 따라 분류하였다. 통계적 유의성의 평가를 위해 Chi-square test를 시행하였다( $\alpha=0.05)$.

결과: 상악 소구치(6.8\%)보다 대구치(10.8\%)에서 구개측 굴곡파절이 높은 빈도로 관찰되었고, 그중 제1대구치(39.1\%)에 서 가장 높은 빈도로 관찰되었다. 연령이 증가할수록 구개측 굴곡파절이 높은 빈도로 관찰되었으며 이는 통계적으로 유 의성이 있었다 $(P<0.05)$. 구개측 굴곡파절의 빈도는 성별에 따른 차이에서는 통계적으로 유의성이 없었으며 $(P>0.05)$, 악궁에 따른 차이에서는 좌측에서 더 높은 빈도로 나타났고 통계적으로 유의성이 있었다 $(P<0.05)$.

결론: 상악 구치에서 구개측 굴곡파절은 상악 제 1 대구치에서 높은 빈도로 관찰되었고, 연령의 증가에 따라 증가하는 양 상을 보였다. 이와 같은 결과는 굴곡파절의 가장 주된 원인이 교합력임을 의미한다.

(구강회복응용과학지 2019;35(4):206-13)

주요어: 치아파절; 치아마모; 치아교모; 교합력

*교신저자: 이경제

(61452) 광주광역시 동구 필문대로 309 조선대학교 치과대학 치과보철학교실

Tel: 062-220-3827 | Fax: 062-232-7776 | E-mail: |kj1998@chosun. ac. kr

접수일: 2019년 9월 2일 | 수정일: 2019년 9월 16일 | 채택일: 2019년 9월 25일 